\title{
Review Article \\ Peroxisome Proliferator-Activated Receptors and Progression of Colorectal Cancer
}

\author{
Dingzhi Wang ${ }^{1}$ and Raymond N. DuBois ${ }^{2}$ \\ ${ }^{1}$ Department of Medicine, Vanderbilt University Medical Center, Nashville, TN 37232, USA \\ ${ }^{2}$ Departments of Gastrointestinal Oncology and Cancer Biology, MD Anderson Cancer Center, \\ The University of Texas, Houston, TX 77030-4009, USA
}

Correspondence should be addressed to Raymond N. DuBois, rdubois@mdanderson.org

Received 14 March 2008; Accepted 29 April 2008

Recommended by Dipak Panigrahy

\begin{abstract}
The peroxisome proliferator-activated receptors (PPARs) are members of the nuclear hormone receptor superfamily. These receptors are also ligand-dependent transcription factors responsible for the regulation of cellular events that range from glucose and lipid homeostases to cell differentiation and apoptosis. The importance of these receptors in lipid homeostasis and energy balance is well established. In addition to these metabolic and anti-inflammatory properties, emerging evidence indicates that PPARs can function as either tumor suppressors or accelerators, suggesting that these receptors are potential candidates as drug targets for cancer prevention and treatment. However, conflicting results have emerged regarding the role of PPARs on colon carcinogenesis. Therefore, further investigation is warranted prior to considering modulation of PPARs as an efficacious therapy for colorectal cancer chemoprevention and treatment.
\end{abstract}

Copyright (c) 2008 D. Wang and Raymond N. DuBois. This is an open access article distributed under the Creative Commons Attribution License, which permits unrestricted use, distribution, and reproduction in any medium, provided the original work is properly cited.

\section{INTRODUCTION}

Understanding the biology of intestinal epithelial cells may reveal the molecular pathogenesis of a number of digestive diseases. One such disease, colorectal cancer (CRC), leads to significant cancer-related morbidity and mortality in most industrialized countries. Initiation and progression of CRC are a complex process that results from the loss of the normal regulatory pathways that govern a balance between epithelial cell proliferation and death. For example, alterations in multiple pathways such as Wnt/APC, COX-2, and Ras are known to play major roles in CRC progression. The standard treatment for advanced malignancies has improved greatly over the past decade but is still not satisfactory. Therefore, significant effort has been exerted to identify novel drug targets for both the prevention and treatment of this disease. One group of compounds found to decrease the risk of colorectal cancer includes nonsteroidal anti-inflammatory drugs (NSAIDs), which target the cyclooxygenase enzymes (COX-1 and COX-2). However, prolonged use of high doses of these inhibitors (except for aspirin) is associated with unacceptable cardiovascular side effects [1-3]. Thus, it is now crucial to develop more effective chemopreventive agents with minimal toxicity and maximum benefit.

Dietary fat intake is an environmental factor that is associated with some human diseases such as diabetes, obesity, and dyslipidemias. Some nuclear hormone receptors play a central role in regulating nutrient metabolism and energy homeostasis. These nuclear receptors are activated by natural ligands, including fatty acids and cholesterol metabolites. Among these receptors, special attention has been focused on the members of the peroxisome proliferatoractivated receptors (PPARs) family, which were initially identified as mediators of the peroxisome proliferators in the early 1990s [4]. PPARs play a central role in regulating the storage and catabolism of dietary fats via complex metabolic pathways, including fatty acid oxidation and lipogenesis [5]. To date, three mammalian PPARs have been identified and are referred to as PPAR $\alpha$ (NR1C1), PPAR $\delta / \beta$ (NR1C2), and PPAR $\gamma$ (NR1C3). Each PPAR isotype displays a tissue-selective expression pattern. PPAR $\alpha$ and PPAR $y$ are predominantly present in the liver and adipose tissue, respectively, while PPAR $\delta$ expresses in diverse tissues [6]. In common with other members of the type II 
steroid hormone receptor superfamily, PPARs are liganddependent transcription factors and form heterodimers with another obligate nuclear receptors, such as retinoid $\mathrm{X}$ receptors (RXRs) [4, 7, 8]. Each PPAR-RXR heterodimer binds to the peroxisome proliferator responsive element (PPRE) located in the promoter region of responsive genes.

It is well established that modulation of PPAR activity maintains cellular and whole-body glucose and lipid homeostases. Hence, great efforts have been made to develop drugs targeting these receptors. For example, PPAR $\gamma$ synthetic agonists, rosiglitazone and pioglitazone, are antidiabetic agents which suppress insulin resistance in adipose tissue. The antiatherosclerotic and hypolipidemic agents including fenofibrate and gemfibrozil are $\operatorname{PPAR} \alpha$ synthetic agonists that induce hepatic lipid uptake and catabolism. Genetic and pharmacological studies have also revealed important roles of $\operatorname{PPAR} \delta$ in regulating lipid metabolism and energy homeostasis. Genetic studies indicate that overexpression of constitutively active $\operatorname{PPAR} \delta$ in mouse adipose tissue reduced hyperlipidemia, steatosis, and obesity induced by either genetics or a high-fat diet. In contrast, $\operatorname{PPAR} \delta$ null mice treated in similar fashion exhibited an obese phenotype [9]. Pharmacologic studies demonstrate that the PPAR $\delta$ selective-agonist (GW501516) attenuated weight gain and insulin resistance in mice fed with high-fat diets [10] and increased HDL-C while lowering tryglyceride levels and insulin in obese rhesus monkeys [11]. Furthermore, preclinical studies revealed that $\operatorname{PPAR} \delta$ agonists diminished metabolic derangements and obesity through increasing lipid combustion in skeletal muscle [12]. These results suggest that PPAR $\delta$ agonists are potential drugs for use in the treatment of dyslipidemias, obesity, and insulin resistance. Therefore, the PPAR $\delta$ agonist (GW501516) is currently in phase III clinical trials to evaluate its use for treatment of patients with hyperlipidemias and obesity. However, recent studies showing that some agonists of PPARs promote carcinogenesis in animal models have raised concerns about using these agonists for the treatment of metabolic diseases. For example, long-term administration of a PPAR $\alpha$ agonist induces the development of hepatocarcinomas in mice but not in PPAR $\alpha$ null animals, conclusively demonstrating that $\operatorname{PPAR} \alpha$ mediates these effects in promoting liver cancer [13]. Furthermore, the PPAR $\delta$ agonist (GW501516) accelerates intestinal polyp growth in $\mathrm{Apc}^{\mathrm{Min} /+}$ mice $[14,15]$. These results raise concerns for developing this class of agents for human use and support the rationale for developing $\operatorname{PPAR} \delta$ antagonists as chemopreventive agents.

\section{PPARs AND COLORECTAL CANCER}

Significant effort has been concentrated on deducing the role of PPARs in CRC and other cancers. A large body of evidence indicates that PPAR $\gamma$ serves as a tumor suppressor. Contradictory evidences suggest that $\operatorname{PPAR} \delta$ can act as either a tumor suppressor or tumor promoter. A few evidences support a role of PPAR $\alpha$ in CRC.

\subsection{PPAR $\alpha$}

Although the tumor-promoting effects of PPAR $\alpha$ in hepatocarcinomas are clear, less is known about the role of PPAR $\alpha$ in human tumors. Generally, activation of PPAR $\alpha$ by exogenous agonists causes inhibition of tumor cell growth in cell lines derived from CRC, melanoma, and glial brain tumors [16-18]. There is no evidence showing that PPAR $\alpha$ expression is elevated in human cancers.

\subsection{PPAR $\gamma$}

The prominent role of PPAR $\gamma$ in regulating cellular differentiation prompted a great effort to investigate the function of PPAR $\gamma$ in cancer field. While PPAR $\gamma$ is elevated in CRC [19], suggesting that this receptor may contribute to tumor biology, studies of PPAR $\gamma$ mutation in CRC from humans, animals, and cultured cells produced controversial results. One study showed that $8 \%$ of primary human colorectal tumors had a loss of function mutation in one allele of the PPAR $\gamma$ gene [20]. Recent data revealed that a Pro12Ala (P12A) polymorphism in the PPAR $\gamma$ gene is associated with increased risk of CRC [21, 22]. These results suggest a putative role for this receptor as a tumor suppressor. In contrast, another study showed that mutant PPAR $\gamma$ gene has not been detected in human colon tumor samples and CRC cell lines, suggesting that PPAR $\gamma$ mutations in human CRC is a rare event [23].

In vitro studies show that activation of PPAR $\gamma$ results in growth arrest of colon carcinoma cells through induction of cell-cycle arrest or/and apoptosis. Several potential downstream targets of PPAR $\gamma$ for mediating antitumor effects of PPAR $\gamma$ have been identified in various cancer cell types. Activation of PPAR $\gamma$ negatively regulatescell cycle progression by modulating a number of cell cycle regulators: (1) inhibiting E2F activity in transformed adipogenic cells [24], (2) Rb hyperphosphorylation in vascular smooth muscle cells and pituitary adenoma cells [25, 26], (3) cyclin D1 expression in Ras-transformed intestinal epithelial cells, pancreatic, or breast cancer cells [27-29], and (4) inducing CDK inhibitor expression such as p18, p21, and p27 in hepatoma cells [30]. Activation of PPAR $\gamma$ has also been reported to inhibit tumor cell growth by upregulation of the transcriptional repressor TSC22 in colon cancer cells [31] and GADD153 in nonsmall-cell lung carcinoma cells [32]. PPAR $\gamma$ agonists induce apoptosis by induction of PTEN expression in pancreatic, breast, and colon cancer cells [33] and inhibition of $\mathrm{NF} \kappa \mathrm{B}$ and $\mathrm{Bcl}-2$ expression in colon cancer cells [34]. Moreover, PPAR $\gamma$ exhibits antiangiogenic effects by inhibiting VEGF expression in tumor cells and VEGF receptors in endothelial cells $[35,36]$. It has also been reported that PPAR $\gamma$ agonists suppress tumor cell invasion in colon and breast cancer cells by downregulation of matrix metalloproteinase-7 (MMP-7) and induction of MMP inhibitors $[37,38]$. In addition, the ability of PPAR $\gamma$ to suppress tumor growth is also through inhibiting $\mathrm{APC} / \beta$ catenin and $\mathrm{COX}-2 / \mathrm{PGE}_{2}$ signaling pathways, which are pivotally involved in colon carcinogenesis [39-42]. 
However, the role of PPAR $\gamma$ in colorectal cancer progression is controversial because there are conflicting results in mouse models of colon cancer. Although PPAR $y$ agonists inhibit colorectal carcinogenesis in xenograft models and in the azoxymethane (AOM)-induced colon cancer model $[43,44]$, these drugs are reported to have both tumorpromoting and tumor-inhibiting effects in a mouse model for familial adenomatous polyposis, the $\mathrm{Apc}^{\mathrm{Min} /+}$ mouse. It has been reported that administration of PPAR $\gamma$ agonists significantly increases the number of colon adenomas in the Apc $\mathrm{Min} /+$ mice [45-47] and even in wild-type C57BL/6 mice [48]. However, other studies show that treatment of 2 different Apc-mutant models $\left(\mathrm{Apc}^{\mathrm{Min} /+}\right.$ and $\left.\mathrm{Apc}^{\Delta 1309}\right)$ with the PPAR $y$ agonist pioglitazone resulted in reduction in the number of both small and large intestinal polyps in a dosedependent manner $[49,50]$. These paradoxical observations appear to have been resolved by genetic studies showing that the heterozygous disruption of PPAR $\gamma$ is sufficient to increase tumor number in AOM-treated mice and that intestinal-specific PPAR $\gamma$ knockout promotes tumor growth in $\mathrm{Apc}^{\mathrm{Min} /+}$ mice $[39,51]$. These genetic evidences support the hypothesis that PPAR $\gamma$ serves as tumor suppressor in colorectal cancer. One possible explanation for the differences in phenotype caused by pharmaceutical versus genetic manipulation of PPAR $\gamma$ in mouse models may be due to the PPAR $\gamma$-independent effect of the agonist drugs, drug doses used, and animal models employed. This controversial extends beyond CRC. For example, data are conflicting from different animal models of breast cancer as well. PPAR $\gamma$ agonist suppresses NMU-induced mammary carcinomas [52]. However, overexpression of a constitutively active form of PPAR $\gamma$ accelerates mammary gland tumor development in MMTV-PyV transgenic mice [53].

\section{3. $P P A R \delta$}

$\operatorname{PPAR} \delta$ has been shown to play an important role in embryo implantation [54], atherogenic inflammation [55], regulating cell survival in the kidney following hypertonic stress [56], and skin following wound injury [57, 58]. The role of PPAR $\delta$ in colorectal carcinogenesis is more controversial than that of PPAR $\gamma$. The first evidence linking the $\operatorname{PPAR} \delta$ to carcinogenesis actually emerged from studies on gastrointestinal cancer. PPAR $\delta$ is elevated in most human colorectal cancers and in tumors arising in the $\mathrm{Apc}^{\mathrm{Min} /+}$ mice, and AOM-treated rats [59, 60]. Importantly, the $\operatorname{PPAR} \delta$ proteins are accumulated only in human CRC cells with highly malignant morphology [61]. Downregulation of PPAR $\delta$ is correlated with antitumor effects of dietary fish oil/pectin in rats treated with radiation and AOM [62]. $\operatorname{PPAR} \delta$ was identified as a direct transcriptional target of APC/ $\beta$-catenin/Tcf pathway and as a repression target of NSAIDs $[59,63]$. A case-control study in a large population showed that the protective effect of NSAIDs against colorectal adenomas was reported to be modulated by a polymorphism in the $\operatorname{PPAR} \delta$ gene [64]. $\operatorname{PPAR} \delta$ expression and activity are also induced by oncogenic K-ras [65]. In addition, COX-2-derived $\mathrm{PGl}_{2}$ directly transactivates $\operatorname{PPAR} \delta[60]$, and COX-2-derived $\mathrm{PGE}_{2}$ indirectly induces
$\operatorname{PPAR} \delta$ activation in CRC, hepatocellular carcinoma, and cholangiocarcinoma cells [66-68]. These studies indicate that $\operatorname{PPAR} \delta$ is a focal point of cross-talk between these signaling pathways.

In a murine xenograft cancer model, the disruption of both PPAR $\delta$ alleles in human HCT-116 colon carcinoma cells decreased tumorigenicity, suggesting that activation of $\operatorname{PPAR} \delta$ promotes tumor growth [69]. However, $\operatorname{PPAR} \delta$ has been reported to have both tumor-promoting and tumorinhibiting effects based on conflicting data obtained from mouse models of colon cancer. For example, activation of $\operatorname{PPAR} \delta$ by a selective synthetic $\operatorname{PPAR} \delta$ agonist (GW501516) or a $\operatorname{PPAR} \delta$ endogenous activator $\left(\mathrm{PGE}_{2}\right)$ accelerates intestinal adenoma growth in $\mathrm{Apc}^{\mathrm{Min} /+}$ mice by promoting tumor cell survival $[14,66]$. A subsequent genetic study showed that deletion of PPAR $\delta$ attenuates both small and large intestinal adenoma growth, and $\operatorname{PPAR} \delta$ is required for the tumorpromoting effects of PPAR $\delta$ ligand (GW501516) and $\mathrm{PGE}_{2}$ in $A p c^{\mathrm{Min} /+}$ mice $[15,66]$. Another study showed that loss of PPAR $\delta$ in Apc $\mathrm{Ain}^{\mathrm{M}+}$ mice significantly reduced growth of tumors larger than a diameter of $2 \mathrm{~mm}$, even though $\operatorname{PPAR} \delta$ deficiency did not affect overall tumor incidence [70]. In contrast to these reports suggesting that PPAR $\delta$ serves as tumor accelerator, recent conflicting reports show that $\operatorname{PPAR} \delta$ deficiency enhances polyp growth in $\mathrm{Apc}^{\mathrm{Min} /+}$ and AOM-treated mice in the absence of exogenous PPAR $\delta$ stimulation [71, 72]. Moreover, a PPAR $\delta$ ligand (GW0742) inhibits colon carcinogenesis in AOM-treated mice but promotes small intestinal polyp growth in $\mathrm{Apc}^{\mathrm{Min} /+}$ mice [73].

One explanation for these disparate results may be due to differences in the genetic background of $\mathrm{Apc}^{\mathrm{Min} /+}$ mice, animal breeding, or possibly to differences in the specific targeting strategy employed to delete $\operatorname{PPAR} \delta$. For example, the average number of polyps in 13-week old $\mathrm{Apc}^{\mathrm{Min} /+}$ mice on a C57BL/6 genetic background is about 50 , while the polyp number in $\mathrm{Apc}^{\mathrm{Min} /+}$ mice on a mixed-geneticbackground $(\mathrm{C} 57 \mathrm{BL} / 6 \times 129 / \mathrm{SV})$ is about 120 . Our results also show that the breeding strategy affects the number and size of polyps in mice even on the same genetic background. Mice generated by breeding female PPAR $\delta^{-/-} / \mathrm{Apc}^{\mathrm{Min} /+}$ with male $\mathrm{PPAR} \delta^{-/-} / \mathrm{Apc}^{+/+}$exhibit increased adenoma number with a larger average size than those obtained by breeding female $\operatorname{PPAR} \delta^{-/-} / \mathrm{Apc}^{+/+}$with male $\operatorname{PPAR} \delta^{-/-} / \mathrm{Apc}^{\mathrm{Min} /+}$. Finally, the PPAR $\delta$ null mice we studied were obtained from Beatrice Desvergne in Switzerland. These mice were generated by deleting exons 4 and 5 encoding the DNA binding domain [74], while Peters group generated the $\operatorname{PPAR} \delta$ knockout mice by inserting a neomycin resistance cassette into the last exon (exon 8) [75]. It has been suggested that the strategy employed to disrupt PPAR $\delta$ by the Peters group might have led to a hypomorphic allele, which retains some aporeceptor function, thus making it difficult to correctly interpret their results. Indeed, conflicting results in the context of embryonic lethality have also been observed from these two PPAR $\delta$ mutant mouse strains $[74,75]$. To further clarify the role of PPAR $\delta$ in colorectal tumorigenesis, it is important to investigate the role of $\operatorname{PPAR} \delta$ in animal models that are dependent on activation of other oncogenes 


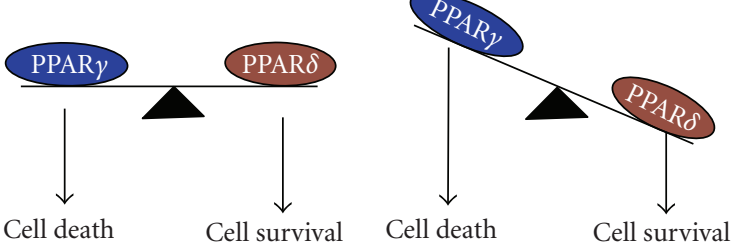

Normal $\longrightarrow$ Tumor

FIgURe 1: A potential model for PPARs regulating colorectal tumor growth.

or disruption of other tumor suppressors to verify our conclusions that activation of PPAR $\delta$ is proneoplastic.

Studies in other types of cancer also support the hypothesis that PPAR $\delta$ serves as a tumor accelerator. A selective PPAR $\delta$ agonist (GW501516) has been shown to stimulate proliferation of human breast, prostate, and hepatocellular carcinoma cells $[68,76,77]$. In a xenograft model, blocking PPAR $\delta$ activation reduced ovarian tumor growth [78]. PPAR $\delta$ knockout mice exhibited significant impaired angiogenesis and tumor growth after these mice were injected s.c. with mouse Lewis lung carcinoma and melanoma cells [79]. In a mouse mammary tumor model, treatment with the PPAR $\delta$ agonist (GW501516) accelerated tumor formation, while a PPAR $\gamma$ agonist (GW7845) delayed tumor growth [80]. Taken together, the role of PPAR $\delta$ in cancer biology remains unclear.

\section{SUMMARY}

Despite extensive research on both PPAR $y$ and PPAR $\delta$ in CRC, the role of these receptors remains highly controversial in this disease. Emerging evidence demonstrates that cooperative interactions between Wnt, COX-2, and PPARs signaling pathways can initiate cellular transformation and promote progression of colorectal cancer. These studies provide support for evaluating the efficacy of PPAR $\delta$ antagonists for cancer prevention and/or treatment. We propose a potential working model as a useful starting point for future studies (see Figure 1).

\section{ACKNOWLEDGMENTS}

This work is supported, in part, by the National Institutes of Health Grants RO1DK 62112, P01-CA-77839, R37DK47297, and P30 CA068485 (RND). RND (R37-DK47297) is recipient of an NIH MERIT award. The authors also thank the National Colorectal Cancer Research Alliance (NCCRA) for generous support (RND).

\section{REFERENCES}

[1] S. D. Solomon, J. J. V. McMurray, M. A. Pfeffer, et al., "Cardiovascular risk associated with celecoxib in a clinical trial for colorectal adenoma prevention," New England Journal of Medicine, vol. 352, no. 11, pp. 1071-1080, 2005.
[2] R. S. Bresalier, R. S. Sandler, H. Quan, et al., "Cardiovascular events associated with rofecoxib in a colorectal adenoma chemoprevention trial," New England Journal of Medicine, vol. 352, no. 11, pp. 1092-1102, 2005.

[3] N. A. Nussmeier, A. A. Whelton, M. T. Brown, et al., "Complications of the COX-2 inhibitors parecoxib and valdecoxib after cardiac surgery," New England Journal of Medicine, vol. 352, no. 11, pp. 1081-1091, 2005.

[4] I. Issemann and S. Green, "Activation of a member of the steroid hormone receptor superfamily by peroxisome proliferators," Nature, vol. 347, no. 6294, pp. 645-650, 1990.

[5] J. P. Berger, T. E. Akiyama, and P. T. Meinke, "PPARs: therapeutic targets for metabolic disease," Trends in Pharmacological Sciences, vol. 26, no. 5, pp. 244-251, 2005.

[6] L. Michalik, B. Desvergne, and W. Wahli, "Peroxisomeproliferator-activated receptors and cancers: complex stories," Nature Reviews Cancer, vol. 4, no. 1, pp. 61-70, 2004.

[7] S. A. Kliewer, B. M. Forman, B. Blumberg, et al., "Differential expression and activation of a family of murine peroxisome proliferator-activated receptors," Proceedings of the National Academy of Sciences of the United States of America, vol. 91, no. 15, pp. 7355-7359, 1994.

[8] D. J. Mangelsdorf and R. M. Evans, "The RXR heterodimers and orphan receptors," Cell, vol. 83, no. 6, pp. 841-850, 1995.

[9] Y.-X. Wang, C.-H. Lee, S. Tiep, et al., "Peroxisomeproliferator-activated receptor $\delta$ activates fat metabolism to prevent obesity," Cell, vol. 113, no. 2, pp. 159-170, 2003.

[10] T. Tanaka, J. Yamamoto, S. Iwasaki, et al., "Activation of peroxisome proliferator-activated receptor $\delta$ induces fatty acid $\beta$-oxidation in skeletal muscle and attenuates metabolic syndrome," Proceedings of the National Academy of Sciences of the United States of America, vol. 100, no. 26, pp. 15924-15929, 2003.

[11] W. R. Oliver Jr., J. L. Shenk, M. R. Snaith, et al., "A selective peroxisome proliferator-activated receptor $\delta$ agonist promotes reverse cholesterol transport," Proceedings of the National Academy of Sciences of the United States of America, vol. 98, no. 9, pp. 5306-5311, 2001.

[12] R. M. Evans, G. D. Barish, and Y.-X. Wang, "PPARs and the complex journey to obesity," Nature Medicine, vol. 10, no. 4, pp. 355-361, 2004.

[13] J. M. Peters, R. C. Cattley, and F. J. Gonzalez, "Role of PPAR $\alpha$ in the mechanism of action of the nongenotoxic carcinogen and peroxisome proliferator Wy-14,643," Carcinogenesis, vol. 18, no. 11, pp. 2029-2033, 1997.

[14] R. A. Gupta, D. Wang, S. Katkuri, H. Wang, S. K. Dey, and R. N. DuBois, "Activation of nuclear hormone receptor peroxisome proliferator-activated receptor- $\delta$ accelerates intestinal adenoma growth," Nature Medicine, vol. 10, no. 3, pp. 245247, 2004.

[15] D. Wang, H. Wang, Y. Guo, et al., "Crosstalk between peroxisome proliferator-activated receptor $\delta$ and VEGF stimulates cancer progression," Proceedings of the National Academy of Sciences of the United States of America, vol. 103, no. 50, pp. 19069-19074, 2006.

[16] M. Grabacka, P. M. Plonka, K. Urbanska, and K. Reiss, "Peroxisome proliferator-activated receptor $\alpha$ activation decreases metastatic potential of melanoma cells in vitro via downregulation of Akt," Clinical Cancer Research, vol. 12, no. 10, pp. 3028-3036, 2006.

[17] N. Strakova, J. Ehrmann, J. Bartos, J. Malikova, J. Dolezel, and Z. Kolar, "Peroxisome proliferator-activated receptors (PPAR) agonists affect cell viability, apoptosis and expression of cell 
cycle related proteins in cell lines of glial brain tumors," Neoplasma, vol. 52, no. 2, pp. 126-136, 2005.

[18] R. Grau, C. Punzón, M. Fresno, and M. A. Iñiguez, "Peroxisome-proliferator-activated receptor $\alpha$ agonists inhibit cyclo-oxygenase 2 and vascular endothelial growth factor transcriptional activation in human colorectal carcinoma cells via inhibition of activator protein-1," Biochemical Journal, vol. 395, no. 1, pp. 81-88, 2006.

[19] R. N. DuBois, R. Gupta, J. Brockman, B. S. Reddy, S. L. Krakow, and M. A. Lazar, "The nuclear eicosanoid receptor, PPAR $\gamma$, is aberrantly expressed in colonic cancers," Carcinogenesis, vol. 19, no. 1, pp. 49-53, 1998.

[20] P. Sarraf, E. Mueller, W. M. Smith, et al., "Loss-of-function mutations in PPAR $\gamma$ associated with human colon cancer," Molecular Cell, vol. 3, no. 6, pp. 799-804, 1999.

[21] M. L. Slattery, K. Curtin, R. Wolff, et al., "PPAR $\gamma$ and colon and rectal cancer: associations with specific tumor mutations, aspirin, ibuprofen and insulin-related genes (United States)," Cancer Causes and Control, vol. 17, no. 3, pp. 239-249, 2006.

[22] S. Landi, V. Moreno, L. Gioia-Patricola, et al., "Association of common polymorphisms in inflammatory genes interleukin (IL)6, IL8, tumor necrosis factor $\alpha, N F K B 1$, and peroxisome proliferator-activated receptor $\gamma$ with colorectal cancer," Cancer Research, vol. 63, no. 13, pp. 3560-3566, 2003.

[23] T. Ikezoe, C. W. Miller, S. Kawano, et al., "Mutational analysis of the peroxisome proliferator-activated receptor $\gamma$ gene in human malignancies," Cancer Research, vol. 61, no. 13, pp. 5307-5310, 2001.

[24] S. Altiok, M. Xu, and B. M. Spiegelman, "PPAR $\gamma$ induces cell cycle withdrawal: inhibition of E2f/DP DNA-binding activity via down-regulation of PP2A," Genes and Development, vol. 11, no. 15, pp. 1987-1998, 1997.

[25] S. Wakino, U. Kintscher, S. Kim, F. Yin, W. A. Hsueh, and R. E. Law, "Peroxisome proliferator-activated receptor $\gamma$ ligands inhibit retinoblastoma phosphorylation and $\mathrm{G}_{1} \rightarrow \mathrm{S}$ transition in vascular smooth muscle cells," Journal of Biological Chemistry, vol. 275, no. 29, pp. 22435-22441, 2000.

[26] A. P. Heaney, M. Fernando, and S. Melmed, "PPAR- $\gamma$ receptor ligands: novel therapy for pituitary adenomas," The Journal of Clinical Investigation, vol. 111, no. 9, pp. 1381-1388, 2003.

[27] S. Kitamura, Y. Miyazaki, S. Hiraoka, et al., "PPAR $\gamma$ agonists inhibit cell growth and suppress the expression of cyclin D1 and EGF-like growth factors in ras-transformed rat intestinal epithelial cells," International Journal of Cancer, vol. 94, no. 3, pp. 335-342, 2001.

[28] C. Qin, R. Burghardt, R. Smith, M. Wormke, J. Stewart, and S. Safe, "Peroxisome proliferator-activated receptor $\gamma$ agonists induce proteasome-dependent degradation of cyclin D1 and estrogen receptor $\alpha$ in MCF-7 breast cancer cells," Cancer Research, vol. 63, no. 5, pp. 958-964, 2003.

[29] M. Toyota, Y. Miyazaki, S. Kitamura, et al., "Peroxisome proliferator-activated receptor $\gamma$ reduces the growth rate of pancreatic cancer cells through the reduction of cyclin D1," Life Sciences, vol. 70, no. 13, pp. 1565-1575, 2002.

[30] H. Koga, S. Sakisaka, M. Harada, et al., "Involvement of $\mathrm{p} 21^{\mathrm{WAF} 1 / \mathrm{Cip} 1}, \mathrm{p} 27^{\mathrm{Kip} 1}$, and $\mathrm{p} 18^{\mathrm{INK} 4 \mathrm{c}}$ in troglitazone-induced cell-cycle arrest in human hepatoma cell lines," Hepatology, vol. 33, no. 5, pp. 1087-1097, 2001.

[31] R. A. Gupta, P. Sarraf, J. A. Brockman, et al., "Peroxisome proliferator-activated receptor $\gamma$ and transforming growth factor- $\beta$ pathways inhibit intestinal epithelial cell growth by regulating levels of TSC-22," Journal of Biological Chemistry, vol. 278 , no. 9 , pp. 7431-7438, 2003.
[32] T. Satoh, M. Toyoda, H. Hoshino, et al., "Activation of peroxisome proliferator-activated receptor- $\gamma$ stimulates the growth arrest and DNA-damage inducible 153 gene in nonsmall cell lung carcinoma cells," Oncogene, vol. 21, no. 14, pp. 2171-2180, 2002.

[33] B. Farrow and B. M. Evers, "Activation of PPAR $\gamma$ increases PTEN expression in pancreatic cancer cells," Biochemical and Biophysical Research Communications, vol. 301, no. 1, pp. 5053, 2003.

[34] G. G. Chen, J. F. Y. Lee, S. H. Wang, U. P. F. Chan, P. C. Ip, and W. Y. Lau, "Apoptosis induced by activation of peroxisomeproliferator activated receptor-gamma is associated with Bcl-2 and Nf- $\kappa \mathrm{B}$ in human colon cancer," Life Sciences, vol. 70, no. 22, pp. 2631-2646, 2002.

[35] X. Xin, S. Yang, J. Kowalski, and M. E. Gerritsen, "Peroxisome proliferator-activated receptor $\gamma$ ligands are potent inhibitors of angiogenesis in vitro and in vivo," Journal of Biological Chemistry, vol. 274, no. 13, pp. 9116-9121, 1999.

[36] D. Panigrahy, S. Singer, L. Q. Shen, et al., "PPAR $\gamma$ ligands inhibit primary tumor growth and metastasis by inhibiting angiogenesis," The Journal of Clinical Investigation, vol. 110, no. 7, pp. 923-932, 2002.

[37] H. Liu, C. Zang, M. H. Fenner, K. Possinger, and E. Elstner, "PPAR $\gamma$ ligands and ATRA inhibit the invasion of human breast cancer cells in vitro," Breast Cancer Research and Treatment, vol. 79, no. 1, pp. 63-74, 2003.

[38] D. Shen, C. Deng, and M. Zhang, "Peroxisome proliferatoractivated receptor $\gamma$ agonists inhibit the proliferation and invasion of human colon cancer cells," Postgraduate Medical Journal, vol. 83, no. 980, pp. 414-419, 2007.

[39] G. D. Girnun, W. M. Smith, S. Drori, et al., "APC-dependent suppression of colon carcinogenesis by PPAR $\gamma$," Proceedings of the National Academy of Sciences of the United States of America, vol. 99, no. 21, pp. 13771-13776, 2002.

[40] H. Inoue, T. Tanabe, and K. Umesono, "Feedback control of cyclooxygenase-2 expression through PPAR $\gamma$," Journal of Biological Chemistry, vol. 275, no. 36, pp. 28028-28032, 2000.

[41] O. Quraishi, J. A. Mancini, and D. Riendeau, "Inhibition of inducible prostaglandin $\mathrm{E}_{2}$ synthase by 15 -deoxy- $\Delta^{12,14}$ prostaglandin $\mathrm{J}_{2}$ and polyunsaturated fatty acids," Biochemical Pharmacology, vol. 63, no. 6, pp. 1183-1189, 2002.

[42] O. Schröder, Y. Yudina, A. Sabirsh, N. Zahn, J. Z. Haeggström, and J. Stein, "15-deoxy- $\Delta^{12,14}$-prostaglandin $J_{2}$ inhibits the expression of microsomal prostaglandin E synthase type 2 in colon cancer cells," Journal of Lipid Research, vol. 47, no. 5, pp. 1071-1080, 2006.

[43] P. Sarraf, E. Mueller, D. Jones, et al., "Differentiation and reversal of malignant changes in colon cancer through PPAR $y$," Nature Medicine, vol. 4, no. 9, pp. 1046-1052, 1998.

[44] E. Osawa, A. Nakajima, K. Wada, et al., "Peroxisome proliferator-activated receptor $\gamma$ ligands suppress colon carcinogenesis induced by azoxymethane in mice," Gastroenterology, vol. 124, no. 2, pp. 361-367, 2003.

[45] A.-M. Lefebvre, I. Chen, P. Desreumaux, et al., "Activation of the peroxisome proliferator-activated receptor $\gamma$ promotes the development of colon tumors in C57BL/6J-APC ${ }^{\mathrm{Min} /+}$ mice," Nature Medicine, vol. 4, no. 9, pp. 1053-1057, 1998.

[46] E. Saez, P. Tontonoz, M. C. Nelson, et al., "Activators of the nuclear receptor PPAR $\gamma$ enhance colon polyp formation," Nature Medicine, vol. 4, no. 9, pp. 1058-1061, 1998.

[47] M. V. Pino, M. F. Kelley, and Z. Jayyosi, "Promotion of colon tumors in $\mathrm{C} 57 \mathrm{BL} / 6 \mathrm{~J}-\mathrm{APC}^{\mathrm{min} /+}$ mice by thiazolidinedione PPAR $\gamma$ agonists and a structurally Unrelated PPAR $\gamma$ agonist," Toxicologic Pathology, vol. 32, no. 1, pp. 58-63, 2004. 
[48] K. Yang, K.-H. Fan, S. A. Lamprecht, et al., "Peroxisome proliferator-activated receptor $\gamma$ agonist troglitazone induces colon tumors in normal C57BL/6J mice and enhances colonic carcinogenesis in $\mathrm{APC}^{1638 \mathrm{~N} /+} \mathrm{Mlh}^{+/-}$double mutant mice," International Journal of Cancer, vol. 116, no. 4, pp. 495-499, 2005.

[49] N. Niho, M. Takahashi, T. Kitamura, et al., "Concomitant suppression of hyperlipidemia and intestinal polyp formation in Apc-deficient mice by peroxisome proliferator-activated receptor ligands," Cancer Research, vol. 63, no. 18, pp. 60906095, 2003.

[50] N. Niho, M. Takahashi, Y. Shoji, et al., "Dose-dependent suppression of hyperlipidemia and intestinal polyp formation in Min mice by pioglitazone, a PPAR $\gamma$ ligand," Cancer Science, vol. 94, no. 11, pp. 960-964, 2003.

[51] C. A. McAlpine, Y. Barak, I. Matise, and R. T. Cormier, "Intestinal-specific PPAR $\gamma$ deficiency enhances tumorigenesis in $\mathrm{APC}^{\mathrm{Min} /+}$ mice," International Journal of Cancer, vol. 119, no. 10 , pp. 2339-2346, 2006.

[52] N. Suh, Y. Wang, C. R. Williams, et al., "A new ligand for the peroxisome proliferator-activated receptor- $\gamma$ (PPAR$\gamma$ ), GW7845, inhibits rat mammary carcinogenesis," Cancer Research, vol. 59, no. 22, pp. 5671-5673, 1999.

[53] E. Saez, J. Rosenfeld, A. Livolsi, et al., "PPAR $\gamma$ signaling exacerbates mammary gland tumor development," Genes and Development, vol. 18, no. 5, pp. 528-540, 2004.

[54] H. Lim, R. A. Gupta, W.-G. Ma, et al., "Cyclo-oxygenase2-derived prostacyclin mediates embryo implantation in the mouse via PPAR $\delta$," Genes and Development, vol. 13, no. 12, pp. 1561-1574, 1999.

[55] C.-H. Lee, A. Chawla, N. Urbiztondo, D. Liao, W. A. Boisvert, and R. M. Evans, "Transcriptional repression of atherogenic inflammation: modulation by $\operatorname{PPAR} \delta$," Science, vol. 302, no. 5644, pp. 453-457, 2003.

[56] C.-M. Hao, R. Redha, J. Morrow, and M. D. Breyer, "Peroxisome proliferator-activated receptor $\delta$ activation promotes cell survival following hypertonic stress," Journal of Biological Chemistry, vol. 277, no. 24, pp. 21341-21345, 2002.

[57] N. Di-Poï, N. S. Tan, L. Michalik, W. Wahli, and B. Desvergne, "Antiapoptotic role of PPAR $\beta$ in keratinocytes via transcriptional control of the Akt1 signaling pathway," Molecular Cell, vol. 10, no. 4, pp. 721-733, 2002.

[58] N. Di-Poï, L. Michalik, N. S. Tan, B. Desvergne, and W. Wahli, "The anti-apoptotic role of PPAR $\beta$ contributes to efficient skin wound healing," Journal of Steroid Biochemistry and Molecular Biology, vol. 85, no. 2-5, pp. 257-265, 2003.

[59] T.-C. He, T. A. Chan, B. Vogelstein, and K. W. Kinzler, "PPAR $\delta$ is an APC-regulated target of nonsteroidal anti-inflammatory drugs," Cell, vol. 99, no. 3, pp. 335-345, 1999.

[60] R. A. Gupta, J. Tan, W. F. Krause, et al., "Prostacyclin-mediated activation of peroxisome proliferator-activated receptor $\delta$ in colorectal cancer," Proceedings of the National Academy of Sciences of the United States of America, vol. 97, no. 24, pp. 13275-13280, 2000.

[61] O. Takayama, H. Yamamoto, B. Damdinsuren, et al., "Expression of PPAR $\delta$ in multistage carcinogenesis of the colorectum: implications of malignant cancer morphology," British Journal of Cancer, vol. 95, no. 7, pp. 889-895, 2006.

[62] J. Vanamala, A. Glagolenko, P. Yang, et al., "Dietary fish oil and pectin enhance colonocyte apoptosis in part through suppression of PPAR $\delta / P G E 2$ and elevation of PGE3," Carcinogenesis, vol. 29, no. 4, pp. 790-796, 2008.

[63] N. Ouyang, J. L. Williams, and B. Rigas, "NO-donating aspirin isomers downregulate peroxisome proliferator-activated rece- ptor (PPAR) $\delta$ expression in $\mathrm{APC}^{\mathrm{min} /+}$ mice proportionally to their tumor inhibitory effect: implications for the role of PPAR $\delta$ in carcinogenesis," Carcinogenesis, vol. 27, no. 2, pp. 232-239, 2006.

[64] C. L. E. Siezen, M. J. Tijhuis, N. R. Kram, et al., "Protective effect of nonsteroidal anti-inflammatory drugs on colorectal adenomas is modified by a polymorphism in peroxisome proliferator-activated receptor $\delta$," Pharmacogenetics and Genomics, vol. 16, no. 1, pp. 43-50, 2006.

[65] J. Shao, H. Sheng, and R. N. DuBois, "Peroxisome proliferatoractivated receptors modulate K-Ras-mediated transformation of intestinal epithelial cells," Cancer Research, vol. 62, no. 11, pp. 3282-3288, 2002.

[66] D. Wang, H. Wang, Q. Shi, et al., "Prostaglandin $E_{2}$ promotes colorectal adenoma growth via transactivation of the nuclear peroxisome proliferator-activated receptor $\delta$," Cancer Cell, vol. 6, no. 3, pp. 285-295, 2004.

[67] L. Xu, C. Han, and T. Wu, "A novel positive feedback loop between peroxisome proliferator-activated receptor- $\delta$ and prostaglandin $\mathrm{E}_{2}$ signaling pathways for human cholangiocarcinoma cell growth," Journal of Biological Chemistry, vol. 281, no. 45, pp. 33982-33996, 2006.

[68] L. Xu, C. Han, K. Lim, and T. Wu, "Cross-talk between peroxisome proliferator-activated receptor $\delta$ and cytosolic phospholipase $\mathrm{A}_{2} \alpha /$ cyclooxygenase-2/prostaglandin $\mathrm{E}_{2}$ signaling pathways in human hepatocellular carcinoma cells," Cancer Research, vol. 66, no. 24, pp. 11859-11868, 2006.

[69] B. H. Park, B. Vogelstein, and K. W. Kinzler, "Genetic disruption of PPAR $\delta$ decreases the tumorigenicity of human colon cancer cells," Proceedings of the National Academy of Sciences of the United States of America, vol. 98, no. 5, pp. 25982603, 2001.

[70] Y. Barak, D. Liao, W. He, et al., "Effects of peroxisome proliferator-activated receptor $\delta$ on placentation, adiposity, and colorectal cancer," Proceedings of the National Academy of Sciences of the United States of America, vol. 99, no. 1, pp. 303308, 2002.

[71] F. S. Harman, C. J. Nicol, H. E. Marin, J. M. Ward, F. J. Gonzalez, and J. M. Peters, "Peroxisome proliferator-activated receptor- $\delta$ attenuates colon carcinogenesis," Nature Medicine, vol. 10, no. 5, pp. 481-483, 2004.

[72] K. R. Reed, O. J. Sansom, A. J. Hayes, et al., "PPAR $\delta$ status and Apc-mediated tumourigenesis in the mouse intestine," Oncogene, vol. 23, no. 55, pp. 8992-8996, 2004.

[73] H. E. Marin, M. A. Peraza, A. N. Billin, et al., "Ligand activation of peroxisome proliferator-activated receptor $\beta$ inhibits colon carcinogenesis," Cancer Research, vol. 66, no. 8, pp. 4394-4401, 2006.

[74] K. Nadra, S. I. Anghel, E. Joye, et al., "Differentiation of trophoblast giant cells and their metabolic functions are dependent on peroxisome proliferator-activated receptor $\beta / \delta$," Molecular and Cellular Biology, vol. 26, no. 8, pp. 3266-3281, 2006.

[75] J. M. Peters, S. S. T. Lee, W. Li, et al., "Growths, adipose, brain, and skin alterations resulting from targeted disruption of the mouse peroxisome proliferator-activated receptor $\beta(\delta)$," Molecular and Cellular Biology, vol. 20, no. 14, pp. 5119-5128, 2000.

[76] R. L. Stephen, M. C. U. Gustafsson, M. Jarvis, et al., "Activation of peroxisome proliferator-activated receptor $\delta$ stimulates the proliferation of human breast and prostate cancer cell lines," Cancer Research, vol. 64, no. 9, pp. 3162-3170, 2004.

[77] B. Glinghammar, J. Skogsberg, A. Hamsten, and E. Ehrenborg, "PPAR $\delta$ activation induces COX-2 gene expression and cell 
proliferation in human hepatocellular carcinoma cells," Biochemical and Biophysical Research Communications, vol. 308, no. 2, pp. 361-368, 2003.

[78] T. Daikoku, S. Tranguch, A. Chakrabarty, et al., "Extracellular signal-regulated kinase is a target of cyclooxygenase1-peroxisome proliferator-activated receptor- $\delta$ signaling in epithelial ovarian cancer," Cancer Research, vol. 67, no. 11, pp. 5285-5292, 2007.

[79] A. Abdollahi, C. Schwager, J. Kleeff, et al., "Transcriptional network governing the angiogenic switch in human pancreatic cancer," Proceedings of the National Academy of Sciences of the United States of America, vol. 104, no. 31, pp. 12890-12895, 2007.

[80] Y. Yin, R. G. Russell, L. E. Dettin, et al., "Peroxisome proliferator-activated receptor $\delta$ and $\gamma$ agonists differentially alter tumor differentiation and progression during mammary carcinogenesis," Cancer Research, vol. 65, no. 9, pp. 3950-3957, 2005. 


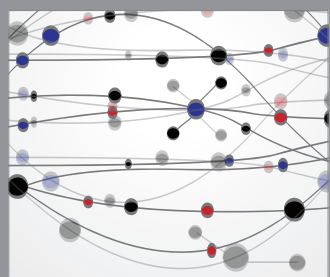

The Scientific World Journal
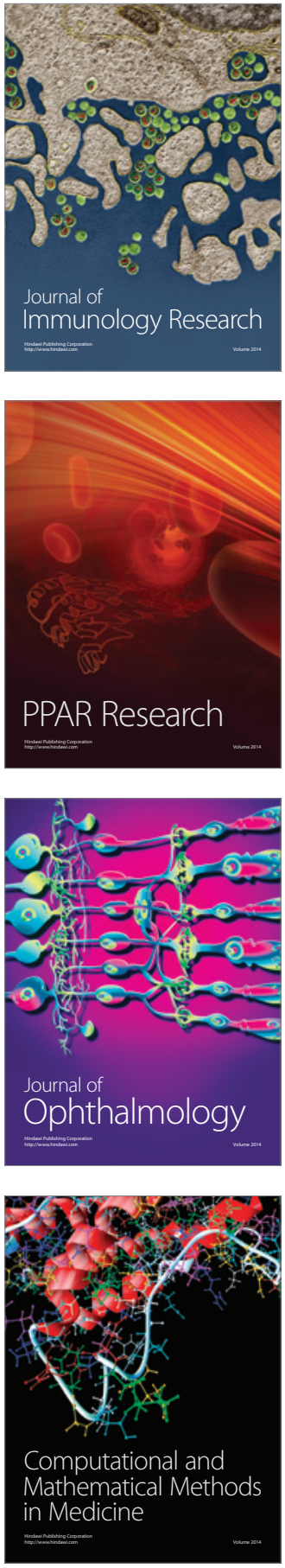

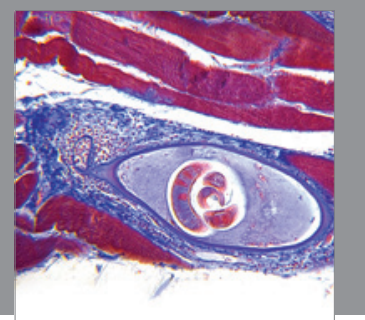

Gastroenterology

Research and Practice
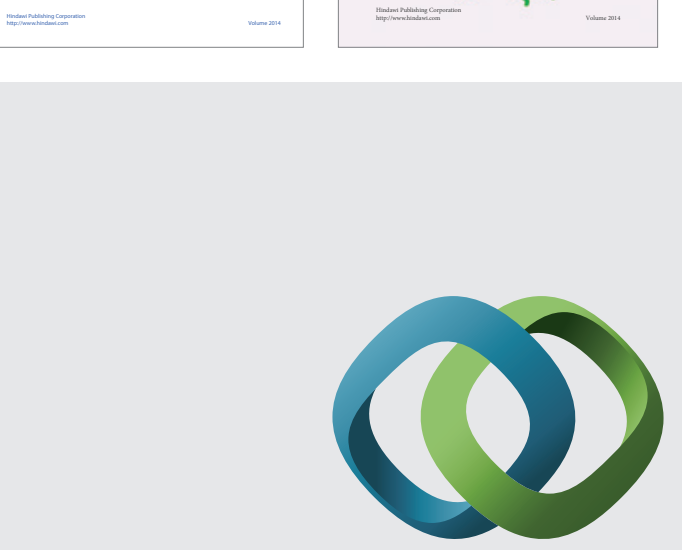

\section{Hindawi}

Submit your manuscripts at

http://www.hindawi.com
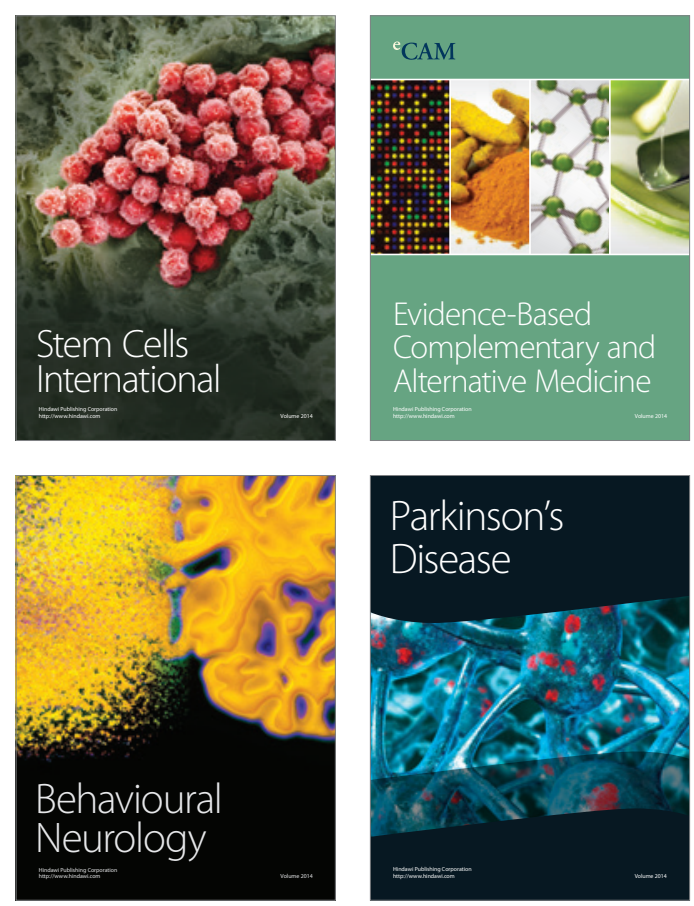

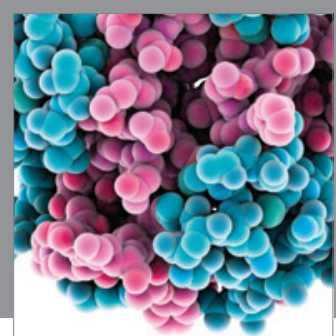

Journal of
Diabetes Research

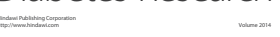

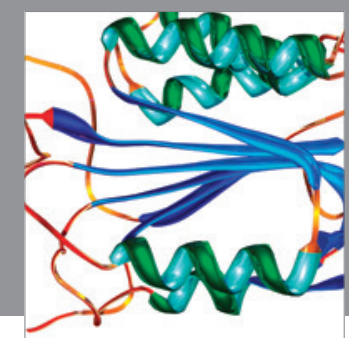

Disease Markers
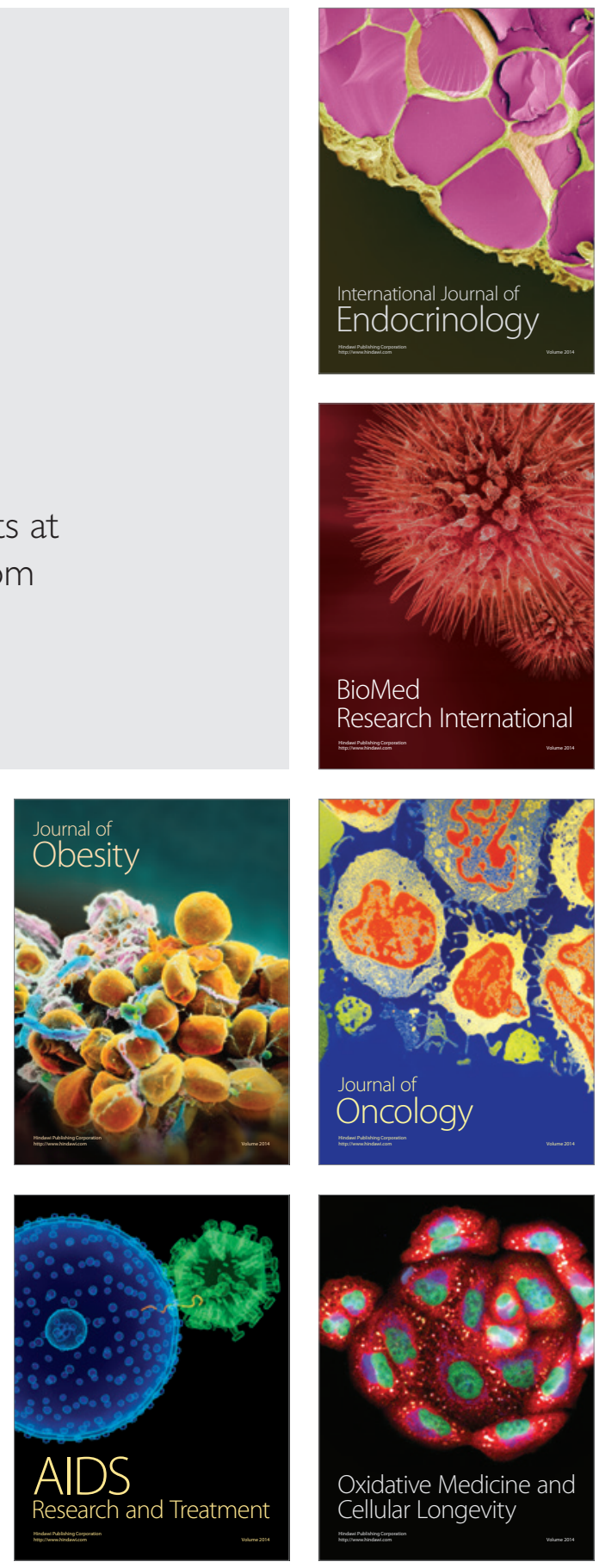